\title{
RELATIONSHIP BETWEEN SLOPE OF THE PLASMA LACTATE ACCUMULATION CURVE AND WORKING CAPACITY IN ANDALUSIAN HORSES
}

\author{
A. MUÑOZ, R. SANTISTEBAN, M. D. RUBIO, C. RIBER, E. I. AGÜERA, F. M. CASTEJÓN \\ Department of Animal Biology, Section of Physiology, Faculty of Veterinary Medicine \\ University of Córdoba, Spain \\ Received September 14, 1998 \\ Accepted January 14, 1999
}

Abstract

Muñoz A., R. Santisteban, M. D. Rubio, C. Riber, E. I. Agüera, F. M. Castejón: Relationship between Slope of the Plasma Lactate Accumulation Curve and Working Capacity in Andalusian Horses. Acta Vet. Brno 1999, 68: 41-50.

The main objective of this study was to analyse the relationship between the slope of the plasma lactate accumulation in response to exercise and working capacity in two groups of Andalusian horses of different age.

The horses were subjected to increasing intensity tests, comprising both submaximal and maximal velocities. Heart rate was monitored throughout the exercise and jugular venous blood samples were withdrawn at rest, after each workload and during the first $30 \mathrm{~min}$. of recuperation. Working capacity was assessed by means of these functional indices: HRmax (maximum mean heart rate during exercise), $V_{\max }$ (maximum velocity), STEPmax (maximum number of workload completed), VLA2 (aerobic threshold), VLA4 (anaerobic threshold), PLA (lactate peak), pHmin (minimum $\mathrm{pH}$ ) and $\mathrm{PCV}_{\max }$ (maximum packed cell volume).

HRmax, pHmin, VLA2, VLA4, STEPmax and $V_{\max }$ were positively correlated with working capacity, whereas PLA and PCV $\max$ were negatively correlated with working capacity. The slope of the plasma lactate accumulation curve were inversely related to VLA2, VLA4, Vmax, STEPmax and $\mathrm{pH}$ min and positively related to HRmax and PCVmax. Besides, the plasma lactate slope was higher in the youngest Andalusian horses.

These results indicated that the slope of the plasma lactate concentrations after several exercise intensities might be considered as a marker of aerobic potential, providing useful information about fitness and training degrees in the Andalusian horse.

Exercise, fitness, heart rate, packed cell volume

Physical exercise requires a balance between production and consumption of energy within working muscles. It has been postulated that there is a critical intensity or threshold above which the cardiovascular, respiratory and/or muscular responses are of insufficient magnitude to supply energy through aerobic pathways. As a consequence, anaerobic pathways become predominant, and large amounts of lactate (LA) are produced. LA is considered to be a small and easily diffusable anion, and it may be translocated rapidly between the water compartments of the body. Muscle LA produced during exercise can be utilised by the active muscles, exported via the blood to other organs, principally liver and heart, or taken up by other muscles with adequate oxygen supply and utilised as a source of fuel (Brooks 1986; Marlin et al. 1987).

Three different models of plasma LA accumulation have been proposed. The single breakaway point is the classical model of aerobic-anaerobic transition. Margaria et al. (1933) established that lactic acid was formed and plasma LA accumulated during times of local muscle hypoxia, such as the onset of exercise and during times of oxygen deficit. 
A three-phase, double breakaway model was defended by Kinderman et al. (1979) in response to threshold LA values of both 2 and $4 \mathrm{mmol} / \mathrm{l}$. According to this second model, $2 \mathrm{mmol} / \mathrm{l}$ represents the upper limit of exclusive aerobic metabolism, and therefore, it should be referred to as the 'aerobic threshold'. An aerobic-anaerobic transition period occurred between plasma LA concentrations of 2 and $4 \mathrm{mmol} / \mathrm{l}$. Finally, a plasma LA level of $4 \mathrm{mmol} / \mathrm{l}$ reflexes the true 'anaerobic threshold', a value above which LA production exceeds its removal and endurance work performance is severely limited.

The exponential model was described by Hughs on et al. (1987), after finding that plasma LA concentrations increased as a continuous function during progressive exercise. This third model suggests that there is no breakaway point at which there is an increased reliance on anaerobic metabolism. By contrast, an exponential increase in the production of energy through glycolytic pathways from the beginning of incremental exercise occurs. This model challenges the existence of critical intensities, LA and ventilatory threshold, upholding the belief that glycolytic energy sources supply an ever-increasing proportion of the total energy expenditure from the onset of incremental exercise. Hughson et al. (1987) hypothesised that a LA slope index would be an indicator of fitness, replacing the previously applied threshold concept.

In the present study, Andalusian horses performed an incremental exercise, during which plasma LA accumulation was studied. The slope and the y intercept of the LA vs. velocity curve were determined. Moreover, working capacity of these animals was assessed by calculating functional indices according to the procedure described in detail by Muñoz (1997) and Muñoz et al. (1997a). Two are the purposes of the present research: 1) To establish if there is a relationship between slope and y intercept of the plasma LA accumulation curve and working capacity in Andalusian horses, as suggested by Hugh son et al. (1987) in humans and 2) To detect differences in these variables between horses with different training level and used for different purposes.

\section{Materials and Methods}

Animals

Thirteen healthy male Andalusian horses were included in this study, seven between 3 and 4 years (group A) and six between 7 and 10 years (group B).

Standardised exercise test (SET). The group A performed a SET (SETa) with two phases of different intensity, separated by a 2-min-rest period. The first phase, of submaximal intensity, was divided into four exercise bouts at velocities of 4.15,5.50, 6.90 and $8.30 \mathrm{~m} / \mathrm{sec}$. A distance of $1000 \mathrm{~m}$ was covered at each velocity and a 2-minuterest period was allowed between them. The second phase, of maximal intensity, consisted of $1000 \mathrm{~m}$ at the maximum velocity the horses were able to reach.

The group B carried out a SET (SETb) with six workloads $(4,6,8,10,12$ and $14 \mathrm{~m} / \mathrm{sec}$ ), covering distances of $400,600,800,1000,1200$ and $1200 \mathrm{~m}$, respectively, at each exercise level. A total distance of $4000-5200 \mathrm{~m}$ was covered. Some horses were unable to achieve the last velocities and the number of steps completed was recorded. Thirty sec. of rest were given between velocities in order to obtain blood samples.

Both SETs were made in a semielliptical sandy track. The procedure used to standardise the velocity has been given elsewhere (Agüera et al. 1995; Muñoz et al. 1997b). An ANOVA showed the lack of significant differences between theoretical or calculated velocities and real or chronometered velocities $(\mathrm{p}<0.01)$ in both tests.

Training protocols

Group A. These horses were subjected to the training programme followed traditionally in their Centre of Training, whose characteristics has been previously reported (Muñoz et al. 1997a). In summary, this programme had a duration of 5 months and was composed of two stages: 1) First stage, lasting for 14 weeks, consisted of daily exercise sessions at trotting and galloping velocities. The duration of these daily sessions was progressively increased from $10 \mathrm{~min}$ to $30 \mathrm{~min}$, at a frequency of 5 times/week. 2) Second stage, lasting for the remaining 6 weeks. At the same frequency as the first stage, the daily schedule included 20-30 min of walking, 25-30 min of trotting and 12-18 min of galloping. This training programme is not intended as a means to prepare horses for competitions. The main aim is to improve physical fitness to guarantee a proper reproductive function.

Group B. The animals of the group B were trained for harness events for at least the last 24 months before the experiment. The training protocol consisted of track exercises 2 days/week for approximately 60 min. During these sessions, animals performed exercise workloads at trotting and galloping velocities (between 4-6 m/sec) in order to improve movement coordination. Moreover, they carried out at least $30 \mathrm{~min}$ of draft-loaded exercises. The 
remaining four days, the horses were trotted and galloped in the field, to potentiate strength and stamina. Besides, they performed uphill exercises to improve endurance capacity and strengthen their musculo-skeletal system.

Heart rate and blood sampling. Heart rate (HR) was monitored throughout both SETs by using a heart rate monitor (Polar Sport Tester) at $5 \mathrm{sec}$. interval. Data were stored in the memory and downloaded to a computer via an interface (Software Heart Rate Monitor).

Blood samples were withdrawn by puncture of the external jugular vein. In the group A, they were taken before the SETa and immediately after finishing each exercise level of the submaximal and maximal phases. In the group $\mathrm{B}$, blood specimens were collected at rest and after each exercise velocity. The samples were placed into two tubes, the first with EDTA-3K for the whole blood determinations and the second with lithium-heparin for plasma analysis. Due to the influence of time of centrifugation in the distribution of LA between red blood cells and plasma (Muñoz et al. 1996), the second tube was immediately centrifuged, and plasma was harvested. All the samples were kept in refrigeration until their latter analysis, performed within 12 hours after extraction.

Blood and plasma determinations. Packed cell volume (PCV) was determined with a semiautomatic analyser (Sysmex-F820) and pH was measured in whole blood with a pH-meter (Checker 1). Plasma LA concentrations were quantified with an analyser (Analox, Champion PLM5), using to an enzymatic method based on the LA oxidation.

Working capacity. Working capacity of the horses was assessed by calculating the following functional indices: maximum mean heart rate during the exercise (HRmax), maximum velocity (Vmax) attained by the animals of the group A during the maximal phase of the SETa and number of exercise levels completed (STEPmax) by the horses of the group B during the SETb. Two indices were calculated by extrapolation in the curve plasma LA concentrations vs. exercise velocity: VLA2 or aerobic threshold, exercise velocity eliciting a plasma LA concentration of $2 \mathrm{mmol} / \mathrm{l}$. and VLA4 or anaerobic threshold, exercise velocity eliciting a plasma LA concentration of $4 \mathrm{mmol} / \mathrm{l}$. This last index is the exercise intensity beyond which plasma LA cannot attain steady state but continues to increase because LA production exceeds LA clearance. Other functional indices were: plasma peak lactate (PLA), maximum plasma LA level, achieved at the end of the exercise or during the first minutes of recuperation, minimum blood $\mathrm{pH}(\mathrm{pHmin})$ and maximum packed cell volume (PCVmax).

Statistical analysis. The exponential plasma LA curve has a y intercept which is the calculated LA at zero speed. An ANOVA (Breakdown one-way analysis; Tukey $t$-test) was performed in order to detect differences in the analysed parameters between both horse groups. Working capacity was evaluated by using a principal component analysis (PCA), which permitted both a study of the relationships between variables (VLA2, VLA4, HRmax, Vmax, STEPmax, PLA, pHmin and PCV max) and a comparison of different individuals with each other. The segregation of horses according to the information provided previously by the PCA was made by a discriminant analysis. Finally, the correlations between working capacity, y intercept and the plasma LA slope were investigated by a linear correlation (Pearson product moment correlation).

\section{Results}

The cardiovascular and metabolic response to the SETs differed significantly between both horse groups. Group A showed higher HR and LA values, lower aerobic and anaerobic thresholds and higher plasma LA slope than group B (Table 1).

Table 1

Mean values $(\mathrm{X} \pm \mathrm{SD})$ of the seven functional indices used to evaluate working capacity, plasma LA accumulation slope and y intercept in both horse groups $\mathrm{A}$ and $\mathrm{B}$ (Number of horses in brackets).

Differences are marked at $\mathrm{p}<0.05$

\begin{tabular}{|c|c|c|c|c|c|c|c|c|c|c|}
\hline $\begin{array}{l}\text { Horse } \\
\text { groups }\end{array}$ & $\begin{array}{c}\text { VLA2 } \\
(\mathrm{m} / \mathrm{sec})\end{array}$ & $\begin{array}{c}\text { VLA4 } \\
(\mathrm{m} / \mathrm{sec})\end{array}$ & $\begin{array}{l}V_{\max } \\
(\mathrm{m} / \mathrm{sec})\end{array}$ & STEPmax & $\underset{(\mathrm{mmol} / \mathrm{l})}{\operatorname{PLA}}$ & $\begin{array}{c}\text { HRmax } \\
\text { (beats/min) }\end{array}$ & $\begin{array}{c}\text { PVCmax } \\
(\%)\end{array}$ & pHmin & $\begin{array}{c}\text { Plasma LA } \\
\text { slope }\end{array}$ & $\begin{array}{c}y \\
\text { intercept }\end{array}$ \\
\hline$\underset{(n=7)}{A}$ & $3.679 \pm 0.5$ & $5.731 \pm 0.2$ & $11.75 \pm 0.1$ & & $25.3 \pm 1.4$ & $195.0 \pm 16$ & $52.93 \pm 4.1$ & $7.071 \pm 0.5$ & $0.337 \pm 0.03$ & $0.345 \pm 0.1$ \\
\hline$\underset{(n=6)}{B}$ & $\begin{array}{c}5.037 \pm 1.1 \\
*\end{array}$ & $\begin{array}{c}7.823 \pm 0.3 \\
*\end{array}$ & $12.33 \pm 0.3$ & $5.17 \pm 0.4$ & $\begin{array}{c}9.617 \pm 2.9 \\
*\end{array}$ & $\begin{array}{c}154.5 \pm 15 \\
*\end{array}$ & $54.53 \pm 7.3$ & $\begin{array}{c}7.773 \pm 0.0 \\
*\end{array}$ & $\begin{array}{c}40.200 \pm 0.02 \\
*\end{array}$ & $0.326 \pm 0.2$ \\
\hline
\end{tabular}

In order to simplify the results, only the two first principal components of the PCA were taken into consideration to assess fitness degree. These two components explained the 42.55 and $28.76 \%$ of the total variation (Fig. 1). The indices located on the right side of the Fig. 1 were inversely correlated with working capacity (PLA and PCVmax), as indicated by the correlations between the functional indices and the first two components axes. The correlation coefficients are shown in brackets in Fig. 1. By contrast, those indices located on 


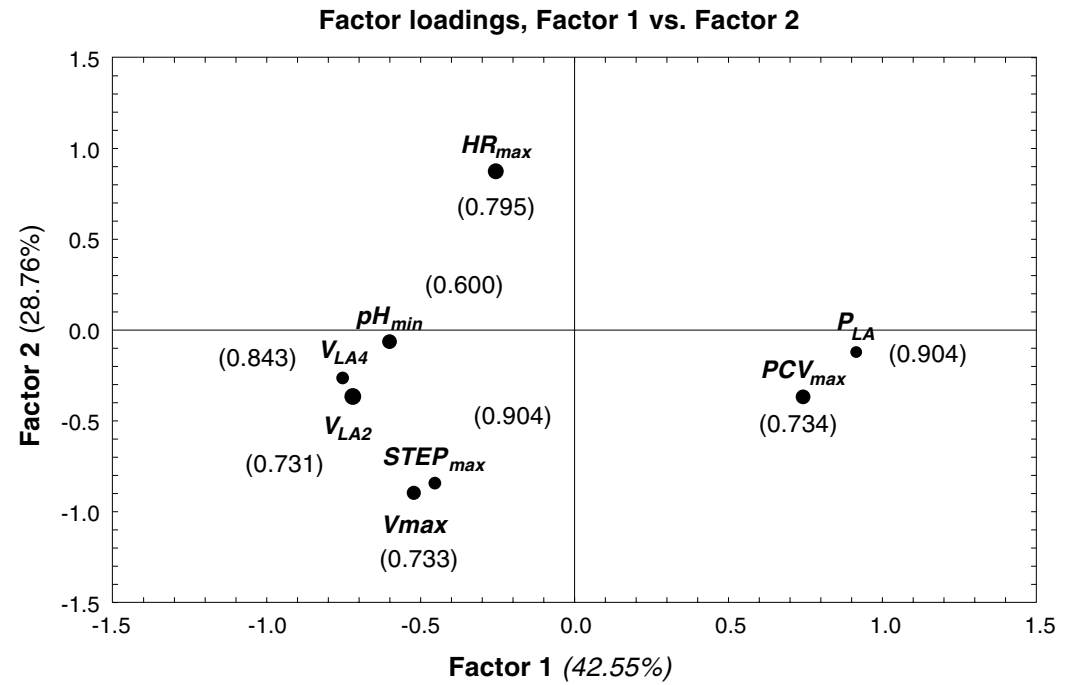

Fig. 1. Plotting of the functional indices on the plan Factor $1 \times$ Factor 2 (Values in brackets indicate the percentage of the total variation explained by the two first principal components)

the left side in the same figure were positively correlated with working capacity (HRmax, pHmin, VLA2, VLA4, STEPmax and Vmax). The most discriminating variables were VLA4, STEPmax and PLA. The results of the discriminant analysis are presented in Fig. 2. The fitter horses are located on the left side of the plot, while the less fit horses are located on the right. The fitness level increases as horses are situated further from the axis centre to the left side.

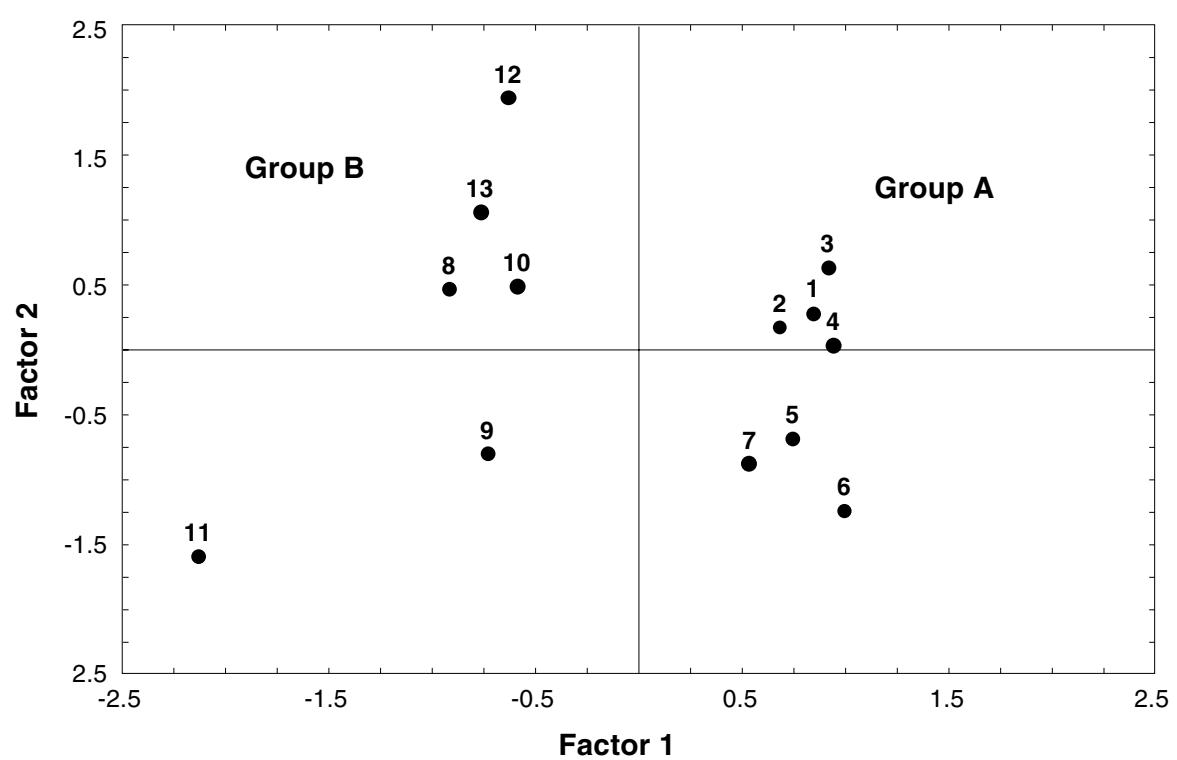

Fig. 2. Graph of the Andalusian horses vs. the predicted values (factor loadings) for the first and second principal components in the first plane of projection 
According to this assertion, horses of group B were fitter than those of group A, and the fittest horse was the number 11.

The plasma LA slope was related to most of the functional indices included in the present study. The highest correlation coefficients were found between the LA slope, VLA4 and pHmin (Table 2). The relationship between the anaerobic threshold and the plasma LA slope is shown in Fig. 3.

Table 2

Correlation matrix along the functional indices, the plasma LA slope and the y intercept in Andalusian horses

\begin{tabular}{|c|c|c|c|c|c|c|c|c|c|}
\hline & Vla4 & $V_{\max }$ & STEPmax & Pla & HRmax & PVCmax & pHmin & LA slope & $y$ intercept \\
\hline VLA2 & $0.880 *$ & $0.750 *$ & $0.680 *$ & $-0.710 *$ & -0.440 & -0.060 & $0.670 *$ & $-0.680 *$ & 0.090 \\
\hline Vla4 & & $0.630 *$ & 0.480 & $-0.940 *$ & -0.570 & -0.110 & $0.910 *$ & $-0.910 *$ & 0.410 \\
\hline$V_{\max }$ & & & $0.930 *$ & -0.510 & -0.560 & -0.010 & 0.530 & $-0.610 *$ & 0.290 \\
\hline STEPmax & & & & -0.350 & -0.520 & 0.020 & 0.350 & -0.410 & 0.160 \\
\hline Pla & & & & & 0.610 & 0.010 & $-0.980 *$ & $0.940 *$ & -0.540 \\
\hline HRmax & & & & & & -0.440 & -0.640 * & $0.710 *$ & -0.730 * \\
\hline PCVmax & & & & & & & 0.050 & -0.030 & 0.200 \\
\hline pHmin & & & & & & & & $-0.930 *$ & 0.570 \\
\hline LA slope & & & & & & & & & -0.740 \\
\hline
\end{tabular}

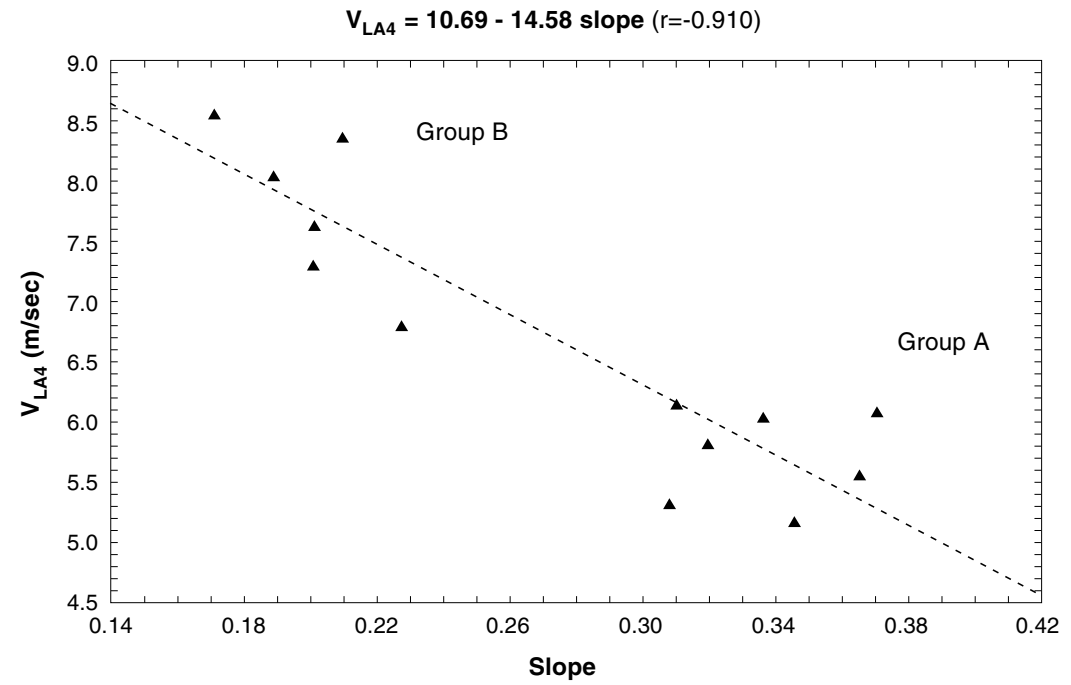

Fig. 3. Correlation between the plasma lactate slope and the anaerobic threshold in both horse groups

\section{Discussion}

The results obtained in the present work suggest that there are marked interindividual differences in the slope of the plasma LA accumulation curve in response to several exercise intensities. These differences might be associated with fitness and training levels. In fact, it can be admitted that the fittest Andalusian horses have lower slope of plasma LA accumulation and lightly higher y intercept values as a response to exercise. 
The PCA seems to be an useful and reliable method to segregate horses with different physical abilities. It has been used to discriminate between some horse breeds (Standardbred trotter, Selle-Franćais, Thoroughbred and Pony) adapted to endurance or speed events (Barrey et al. 1989). Similarly, it has been applied to the assessment of physiological changes linked to a training programme (V alette et al. 1996). More recently, this statistical procedure permitted the discrimination of both Andalusian and Anglo-Arabian horses in function of fitness level by taking into account the cardiovascular, haematological, metabolic and locomotor adaptations to an increasing intensity test (Muñoz 1997; Muñoz et al. 1997a).

In the present research, the most discriminating variables were PLA, STEPmax and VLA4, similar results to those previously documented for the same equine breed (Muñoz et al. 1997a). In both researchs, PCVmax and PLA were inversely correlated with performance, whereas VLA2, VLA4, pHmin, Vmax and HRmax were positively correlated with performance. These findings indicate that the influence of physical potential on these variables is partially independent of the characteristics of the exercise, at least once a determined exercise intensity is attained. In this study, both horse groups were subjected to two absolute maximal effort tests. Group A covered $1000 \mathrm{~m}$ at the maximum speed $(11.5 \pm 0.3 \mathrm{~m} / \mathrm{sec})$. Similarly, group B carried out the last exercise bout at maximal speed, being $12 \mathrm{~m} / \mathrm{sec}$ for 5 horses and $14 \mathrm{~m} / \mathrm{sec}$ for 1 horse. Despite the maximal velocity reached by the animals, relative exercise intensities significantly differed between both horse groups. HR values were near $200 \mathrm{bpm}$ and plasma LA concentrations were higher than $25 \mathrm{mmol} / \mathrm{l}$ after SETa. It has been documented that immediately after racing Thoroughbred and Standardbred horses present HR values ranging between 220 and 240 bpm (Krzywanek et al. 1970) and plasma LA concentrations of $30 \mathrm{mmol} / \mathrm{l}$ respectively (Essén-Gustavs son et al. 1997; R onéus and Essén-Gustavsson 1997). Conversely, relative physical effort performed by group B was of submaximal intensity. Thus, maximum mean HR and plasma LA level were $155 \mathrm{bpm}$ and $10 \mathrm{mmol} / \mathrm{l}$.

In both groups of animals, a negative correlation between PLA and working capacity was found. These results are in disagreement with those presented by other authors, as Saibene et al. (1985), Bayly et al. (1987) and Harkins et al. (1993). These investigators demonstrated higher plasma LA in faster and better performer horses in distances lesser than $2000 \mathrm{~m}$. Similarly, in a study in Standardbred trotters with a wide range of racing abilities, blood LA was greater in superior performing horses after races of $2100 \mathrm{~m}$ (Räsänen et al. 1995).

McMiken (1983) suggested that energy production is predominantly anaerobic for the first 40 to $50 \mathrm{sec}$ (approximate distance of 650 to $800 \mathrm{~m}$ for a Thoroughbred), after which time the importance of aerobic energy supplies increase susbstancially. The Andalusian horses of our study covered a total distance near of $5000 \mathrm{~m}$, and as they depended in a great extent of aerobic metabolism, and hence the inverse relationship between PLA and working capacity.

In spite of this assertion, PCVmax had a negative effect on working capacity. Red blood cell volume (PCV) is though to be an expression of the oxygen transport capacity of the cardiovascular system of the horse (Pers s on 1967). However, PCV is a relative value, as it depends on the degree of splenic mobilisation and fluid losses (breathing, sweating and intercompartmental shifts). The release of red blood cells is proportionally related to the exercise intensity and catecholamines release, which is higher in maximal than submaximal exercises (Engelhard 1977). Consequently, PCV is not a good indicator of the capacity to provide $\mathrm{O}_{2}$ to working muscles. The negative relationship between PCVmax and working capacity has been previously found in Andalusian horses ( Muñoz et al. 1997a) and it might indicate a negative action of an increased blood viscosity on the $\mathrm{O}_{2}$ transport and delivery system to skeletal muscles. 
The plasma LA level of $4 \mathrm{mmol} / \mathrm{l}$ is considered to be the approximate level of exerciseinduced onset of plasma LA accumulation (OPLA) and of the anaerobic threshold (Kinderman et al. 1979; Perss on 1983). VLA4 would therefore be comparable to the VOPLA in man and would consequently act as an marker of endurance performance capacity. In a recent study, nevertheless of the breed and training levels, VLA4 was one of the most discriminating index according to fitness level (Muñoz 1997). In the present investigation, VLA4 was significantly higher in group B, which could have been due to the longer, most exhaustive and controlled training programme, although the effect of age should be taken into consideration. The aerobic power and the exercise capacity increased with age, whereas anaerobic power was already well developed even at a young age in both Thoroughbred and Standardbred. The increased aerobic power in adults is the result of a transformation of type IIB to type IIA fibres in the muscles (Ronéu s 1992). As a result, the activities of the enzymes involved in the cycle of Krebs, fatty acid oxidation and glucose phosphorylation increased. By contrast, key enzymes representing glycogen breakdown and pyruvate reduction pathways showed lower activities in mature horses (EssénGustavss on 1990). The Andalusian horses of group B were older and more trained than those of group A. It has been shown that sexual maturity is attained at the age of three years in Warm-blooded horses, whereas body development, at least in racehorses in training, is not completed until the age of four years in mares and five years in stallions (Ronéus et al. 1991). According to this idea, horses of group A were not completely matured from a physiological point of view. However, the previous results were presented for Standardbred racehorses, and the age at which an Andalusian horse can be considered physiologically matured is unknown. Although some interbreed comparative studies between foals and adults Andalusian, Anglo-Arabian and Arabian horses have been made (Castejón et al. 1994; Rubio et al. 1995), no research exists regarding foals and adult Andalusian horses.

An important discriminating index in group B was the number of workloads completed. The best performing individual was the horse No. 11. It was the only horse which was able to reach $14 \mathrm{~m} / \mathrm{sec}$, and it presented the highest VLA4 and the lowest PLA, PCVmax and plasma LA slope. Surprisingly, Vmax was not an important index to segregate horses in group A. A possible explanation for this result could be the similar Vmax reached by the animals. In fact, Vmax ranged between a minimum value of 9.525 and a maximum of $12.42 \mathrm{~m} / \mathrm{sec}$.

The plasma LA slope was positively correlated with PLA, but no correlation between this slope and PCVmax was detected. It can be thought that the lack of a significant relationship emphasised the poor information provided by PCVmax in relation to aerobic capacity. The negative correlations between VLA2, VLA4, Vmax, STEPmax and pHmin with LA slope suggest that less fit horses presented a more glycolytic response to both maximal and submaximal intensity exercises. This result was somewhat controversial as during submaximal exercises, fit horses produced less LA, but conversely, they produced more LA during a maximal test, showing their reliance on glycolytic pathways for ADP rephosphorylation. However, these ideas have been described for Thoroughbred and Standardbred horses. These breeds are characterised by having a lower percentage of I fibres (Thoroughbred: $13 \%$ and Standardbred: $23 \%$ ), but a higher percentage of IIB fibres (Thoroughbred: $41 \%$ and Standardbred: $35 \%$ ) than the Andalusian breed (I: $27.7 \%$ and IIB: 29\%) (Valberg 1987; López-Rivero et al. 1990). It is known that muscle composition strongly modifies the metabolic response to exercise. The lower percentage of non-oxidative fast-twitch fibres in Andalusian horses could have made this breed more dependent on aerobic metabolism, even at short distance exercise. In this case, the fittest animals would be able to perform short and brief workload with less LA production. 
It may be supposed that the plasma LA slope is modified by training. In the present study, LA slope was significantly lower in group B $(0.200 \pm 0.02)$ than in group A $(0.337 \pm 0.03)$. Valette et al. (1989) observed a change in plasma LA slope in function of the training programme. An endurance training produced a flat slope, whereas a speed training increased the slope. Consequently, it seems that horses with a well-developed stamina present lower LA slope in response to a SET.

The positive correlation between HRmax and LA slope was an unexpected result. It is a known fact that the HR response to exercise is lower in trained and fit horses, and relatively higher in untrained, unfit animals or in individuals insufficient in cardiocirculatory terms (Persson 1983). By contrast, in our study, HRmax had a positive influence on physical fitness. Once the horses achieved different maximal velocities during the SETs, the percentage of HRmax at which horses work during the last exercise bouts would not represent the degree of cardiovascular fitness. Moreover, it is known that cardiac output (CO) increase depends more on the HR at high speed that on the stroke volume (SV). Thereby, a higher $\mathrm{HR}$ would have triggered greater $\mathrm{CO}$, providing more oxygen to the working muscles.

The y intercept values were inversely linked to plasma LA slope and PLA. No other relationships were found. That suggests that resting LA values are of little benefit in predicting submaximal and maximal effort performances.

In summary, plasma LA increased more quickly per velocity increases in unfit than in fit Andalusian horses during both maximal and submaximal exercise intensities. Besides, the plasma LA slope was significantly lower in more trained animals. Consequently, it can be considered as an marker of the aerobic potential, helping in the assessment of fitness level, once the correlation coefficient between the LA slope and the anaerobic threshold is -0.910 . However, the LA slope cannot replace the concept of anaerobic threshold, as the latter index represents the optimal training intensity to enhance both oxidative and glycolytic capacities. Conversely, y intercept did not provide an extra information about fitness level, as it showed no significant correlations with the other functional indices.

\section{Vztah mezi akumulací laktátu a pracovní kapacitou andaluských koní}

Ć́lem studie bylo analyzovat vztah mezi křivkou plazmatické akumulace laktátu jako odpovědi na trénink a pracovní kapacitu u dvou skupin andaluských koní různého věku.

Koně byli podrobeni testům se zvětšující se zátěží při submaximální a maximální rychlosti. Srdeční frekvence byla sledována po celou dobu zátěže a vzorky jugulární krve byly odebrány v klidu, po každé zátěži a během prvních 30 minut po ní.

Pracovní kapacita byla měřena pomocí následujících funkčních ukazatelů: HRmax (maximální srdeční frekvence během zátěže), Vmax (maximální rychlost) STEPmax (maximální počet pracovních záteží), VlA2 (aerobní práh), VlA4 (anaerobní práh) PLA (maximální koncentrace laktátu), pHmin (minimální pH) a PCVmax (maximální hodnoty hematokritu).

HRmax, pHmin, VLA2, Vmax, STEPmax a Vmax byly pozitivně korelovány s pracovní kapacitou, zatímco hodnoty PLA a PCVmax byly korelovány negativně s pracovní kapacitou zvířat. Sklon křivky akumulace laktátu v krevní plazmě byl v inverzním vztahu k Vmax, Vmax, Vmax , STEPmax a pHmax, a v pozitivním vztahu k HRmax a PCVmax . U nejmladších koní byl sklon křivky koncentrace laktátu vyšší.

Tyto výsledky ukazují, že sklon křivky koncentrace laktátu v krevní plazmě po tréninku různé intenzity lze pokládat za marker aerobního potenciálu, který podává užiteční informace o zdatnosti (,fitness“) a stupni trénovanosti andaluských koní.

Acknowledgements

The present research was supported by the Andalusian Research Council (Group AGR-0111) and a fellowship from the University of Córdoba. The authors wish to thank the staff of the Centres of Selection and Training of the 
Military Stud of Jerez de la Frontera and Córdoba. We wish also to thank the riders who willingly cooperated in the training programmes and the exercise tests. The statistical help of Mr. Joaquín Reyes is much appreciated.

\section{References}

AGÜERA, E. I., RUBIO, D., VIVO, R., SANTISTEBAN, R., AGÜERA, S., MUÑOZ, A., CASTEJÓN, F. M. 1995: Heart rate and plasma lactate responses to training in Andalusian horses. J. Equine Vet. Sci. 15: 532-536 BARREY, E., VALETTE, J. P., WOLTER, R. 1989: Étude multifactorielle de l'aptitude a l'effort chez le cheval de selle. Ann. Zootech. 38:157-169

BAYLY,W. M., GRANT, B. D., PEARSON, R. C. 1987: Lactate concentrations in Thoroughbred horses following maximal exercise under field conditions. In: GILLESPIE, J.R. and ROBINSON, N.E (eds.), Equine Exercise Physiology 2. ICEEP Publications. Davis. CA. pp. 426-437

BROOKS, G. A. 1986: The lactate shuttle during exercise and recovery. Med. Sci. Sports Exerc. 18(3): 360-368

CASTEJÓN, F., RUBIO, D., TOVAR, P., VINUESA, M., RIBER, C. 1994: A comparative study of aerobic capacity and fitness in three different horse breeds (Andalusian, Arabian and Anglo-Arabian). J. Vet. Med. A. 41: 645-652

ENGELHARD, W. V. 1977: Cardiovascular effects of exercise and training in horses. Adv. Vet. Sci. Comp. Med. 21: $173-205$

ESSÉN-GUSTAVSSON, B. (1990): Training effects on skeletal muscle. In: Int. Equine Sport Med. Proceed. pp. 18-23

ESSÉN-GUSTAVSSON, B., RONÉUS, N., PÖSÖ, A. R. 1997: Metabolic response in skeletal muscle fibres of Standardbred trotters after racing. Comp. Biochem. Physiol. B. Biochem. Mol. Biol. 117: 431-436

HARKINS, J. D., BEADLE, R. E., KAMERLING, S. G. 1993: The correlation of running ability and physiological variables in Thoroughbred racehorses. Equine Vet. J. 25: 53-60

HUGHSON, L., WEISIGER, K. H., SWANSON, G. D. 1987: Blood lactate concentration increases as a continuous function in progressive exercise. J. Appl. Physiol. 62: 1975-1981

KINDERMAN, W., SIMON, G., KEUL, J. 1979: The significance of the aerobic-anaerobic transition for determination of workload intensities during endurance training. Eur. J. Appl. Physiol. 42: 25-34

KRZYWANEK, H., WITTKE, G., BAYER, A. 1970: The heart rates of Thoroughbred horses during a race. Equine Vet. J. Suppl. 9: 26-35

LÓPEZ-RIVERO, J. L., AGÜERA, E., MONTERDE, J. G., DIZ, A., VIVO, J. 1990: Fibre size and composition of the middle gluteal muscle of the Andalusian horse. Equine Vet. J. 22: 286-287

MARGARIA, R., EDWARDS, H., DILL, D. 1933: The possible mechanisms of contracting and paying the oxygen debt and the role of lactic acid in muscular contractions. Am. J. Physiol. 106: 689-715

MARLIN, D. J., HARRIS, R. C., HARMAN, J. C., SNOW, D. H. 1987: Influence of post-exercise activity on rates of muscle and blood lactate disappearance in the Thoroughbred horse. In: ROBINSON, N. E. and GILLESPIE, J. R. (eds). Equine Exercise Physiology 2. ICEEP Publications. Davis. CA, pp. 320-331

MCMIKEN, D. F. 1983: An energetic basis of equine performance. Equine Vet. J. 15: 123-133

MUÑOZ, A. 1997: Evaluación de la capacidad de rendimiento físico en caballos de diversas razas mediante índices de funcionalidad. Respuesta a un entrenamiento programado (Assessment of the physical potential in horses of different breeds by functional indices. Response to a training program). In: PhD. Thesis. University of Córdoba, $287 \mathrm{p}$.

MUÑ̃Z, A., CASTEJÓN, F. M., RUBIO, M. D., VIVO, R., AGÜERA, E. I., ESCRIBANO, B. M., SANTISTEBAN, R. 1996: How erythrocyte and plasma lactate concentrations are related in Andalusian horses during an exercise test and recuperation. J. Equine Sci. 7: 35-42

MUÑOZ, A., SANTISTEBAN, R., RUBIO, M. D., VIVO, R., AGÜERA, E. I., ESCRIBANO, B. M., CASTEJÓN, F. M. 1997a: Functional evaluation indices in the Andalusian horse. J. Vet. Med. Sci. 59: 745-750

MUÑOZ, A., SANTISTEBAN, R., RUBIO, M. D., VIVO, R., AGÜERA, E. I., ESCRIBANO, B. M., CASTEJÓN, F. M. 1997b: Training as an influential factor on the locomotor pattern in Andalusian horses. J. Vet. Med. A 44: 473-480

PERSSON, S. G .B. 1967: On blood volume and working capacity in horses. Acta Vet. Scand. 19: 1-189

PERSSON, S. G. B. 1983: Evaluation of exercise tolerance and fitness in the performance horse. In: Equine Exercise Physiology (Snow, D. H., Persson, S. G. B. and Rose, R. J., eds). Granta Editions. Cambridge. pp. 441457

RÄSÄNEN, L. A., LAMPINEN, K. J., PÖSÖ, A. R. 1995: Responses of blood and plasma lactate and plasma purines to maximal exercise and their relationship to performance in Standardbred trotters. Am. J. Vet. Res. 56: 1651-1656

RONÉUS, M. 1992. In: Muscle characteristics in horses in relation to age, sex and training. PhD Thesis. Swedish University of Agricultural Sciences. Uppsala.

RONÉUS, M., LINDHOLM, A., ASHEIM, A. 1991: Muscle characteristics in Thoroughbreds of different ages and sexes. Equine Vet. J. 23: 207-210

RONÉUS, N., ESSÉN-GUSTAVSSON, B. 1997: Skeletal muscle characteristics and metabolic response to exercise in young Standardbreds. Am. J. Vet. Res. 58: 167-170 
RUBIO, M. D., MUÑOZ, A., SANTISTEBAN, R., TOVAR, P., CASTEJÓN, F. M. 1995: Comparative hematological study of two breeds of foals (Andalusian and Arab) subjected to exercise of progressive intensity. J. Vet. Med. Sci. 57: 311-315

SAIBENE, F., CORTILI, G., GAVATTI, P., SALA, A., FAINA, M., SARDELLA, F. 1985: Maximal anaerobic (lactic) capacity and power of the horse. Equine Vet. J. 17: 130-132

VALBERG, S. 1987: Metabolic response to racing and fibre properties of skeletal muscle in Standardbred and Thoroughbred horses. J. Equine Vet. Sci. 7: 6-12

VALETTE, J. P., BARREY, E., GARBASI, C., WOLTER, R. 1989: Critères experimentaux d'appreciation de l'aptitude sportive du cheval. In: Compte-rendu de la 15ème Journée d'etude. Paris.

VALETTE, J. P., HEILES, P. H., WOLTER, R. 1996: Multivariate analysis of exercise parameters measured during the training of Thoroughbred racehorses. Pferdeheilkunde 12: 470-473 